\title{
EUCLIDES DA CUNHA: O SERTANEJO E A SIMBOLOGIA DO PODER NO BRASIL
}

\author{
Euclides da Cunha: The backlander and the simbology of power in Brazil
}

\section{Ricardo Santos Sousa*}

\begin{abstract}
RESUMO: O presente artigo trata da construção de símbolos nacionais, tomando como princípio que sistemas políticos carecem de sustentação a nível de representação simbólica. Fazemos uma análise da falência dos signos da monarquia brasileira e a ascensão da republica que urgia em construir novos símbolos. Dessa forma os sertanejos ligados ao movimento de Antônio Conselheiro foram elencados nesse imaginário à posição de inimigos da República. O olhar de Euclides da Cunha, embora eivado pelo racialismo científico, resgatou, em alguma medida, a dimensão de humanidade do sertanejo.
\end{abstract}

Palavras-chave: Raça, nacionalismo, construção simbólica

\begin{abstract}
The curent article aims to show the construction of national symbles, taking as principle that political sistems need to suport themselves with the symbolic representation. In this way we propose a reflection over the fall of the brazilian monarch and the rise of the Republic who urged to construc there own symbles. Therefore, the backlanders following Antônio Conselheiro were elected as representatio of enemies of the Republic. The view on the backlands of the Northeastern Brazil by Euclides da Cunha, even thought riddled with scientific racialism, rescued, in some dimention the humanity of the backlander.
\end{abstract}

Keywords: Race, nationalism. Sybolic construction

\section{Theodoro Sampaio: homenagem ao amigo Euclides da Cunha - um reflexo sensível}

No ano de 1919, o engenheiro Theodoro Sampaio, fez uma homenagem póstuma ao colega de profissão e literato Euclides da Cunha. Naquele momento completavam-se dez anos da sua trágica morte.

Theodoro Sampaio, era um homem bastante erudito, e como Euclides da Cunha não se ateve somente à engenharia, antes circulou por várias áreas do conhecimento como etnografia, história, geologia, linguística etc ${ }^{1}$. Seu contato com Euclides da Cunha se deu a partir de 1892 e se estreitou alguns anos depois quando ambos trabalharam como engenheiros juntos à Superintendência de Obras, ligada à Secretaria de Obras Públicas de São Paulo.

A citada homenagem que Theodoro Sampaio fez ao falecido era uma análise singular da figura de Euclides da Cunha. Chama a atenção alguns pontos pouco comuns em necrológios, que em geral são absolutamente laudatórios, procurando apagar qualquer traço que não enfoque

\footnotetext{
* Doutor em História das ciências e da Saúde pela Casa de Oswaldo Cruz, Professor DE vinculado ao Departamento de História da Universidade Estadual do Sudoeste da Bahia - UESB. E-mail: ricsousa14@gmail.com ORCID: https://orcid.org/0000-0001-6477-8645

1 Ver: SOUSA. Ricardo. Theodoro Sampaio, Friedrich Ratzel e os Sertões de Euclides da Cunha. Ver. Intellèctus, ano XIX, n. 1, 2020, p. 90-113.
} 
atributos olímpicos do homenageado.

O Texto em memória do amigo é, no entanto, marcado pela humanidade do autor de $O s$ Sertões, inclusive com trechos que revelam o tédio que o mortificava. ou ainda as dificuldades alimentares do companheiro.

De volta dos seus trabalhos de campo trazia um ar de tédio a trair-lhe uma repugnância invencível. Não que a vida ativa de engenheiro lhe pesasse; mas porque não encontrava na função, como exercida, a superior elevação capaz de o libertar da pasmaceira de uma técnica que lhe parecia duvidosa. (SAMPAIO, 2000, P.86).

Outra debilidade revelada na homenagem póstuma são as dificuldades alimentares de Euclides da Cunha.

À mesa o Euclides era um torturado a quem as iguarias faziam mais medo do que as carabinas da jacunçada revolta na caatinga. Comer fosse o que fosse era-lhe um tormento, por mais inocente que the parecesse a iguaria e isso notei-lhe sempre antes como depois da sua visita a Canudos. [...] Mordiscava, não comia, e ainda assim se enchia de receito. Não sei se mais tarde essa inapetência nervosa se lhe dissipou. O que posso dizer é que o autor de Os Sertões, do À margem da História, do Peru Versus Bolívia de tantos outros escritos, intérpretes da natureza brasílica, era um doente, talvez imaginário, mas de fato um doente. (SAMPAIO, 2000, p. 91).

Não havia, entretanto, nas revelações de Theodoro Sampaio a intenção de detratar a memória de Euclides da Cunha. Nas correspondências deste, era comum que compartilhasse as suas inquietações, seu tédio, seu sentimento de que estava a fazer de sua vida algo que na verdade não lhe aprazia. Aquela não era uma situação nova, mas desde os tempos da carreira militar, Euclides da Cunha sentia-se deslocado, e por conseguinte, procurava em mudanças sucessivas nos rumos de sua vida uma razão maior para sua existência.

Soube aqui que se acha em plena organização a Escola de Engenharia daí. Imediatamente lembrei-me de uma aspiração antiga: abandonar uma farda demasiadamente pesada para os meus ombros e passar a vida numa função mais tranquila, mais fecunda e mais nobilitadora. (Carta a Porchat-Rio de Janeiro, 7 de junho de 1892) (GALVÃO 1997, p.31).

Um olhar mais apurado na homenagem de Theodoro Sampaio a Euclides da Cunha e percebemos que o autor procurava mostrar como o conflito de Canudos trouxe ao colega de profissão, em alguma medida, a paixão que aquele procurava para que sua existência adquirisse algum significado grandioso

Uma vez tornou-me mais depressa do interior, e vinha mais animado. Era outro e tinha como que um vago pressentimento de que o seu destino ia mudar. Aquela pasmaceira de tantos anos ia ter o seu fim.

Foi quando se ateou a guerra de Canudos no íntimo dos sertões baianos, em 1896, após o insucesso de suas sucessivas expedições mandadas contra os jagunços fanatizados de Antônio Conselheiro (SAMPAIO, 2000, p.87).

Theodoro Sampaio, conhecia bem a região do conflito no Norte baiano, pois havia participado em 1879 como segundo engenheiro da Comissão Hidráulica, liderada pelo estadunidense William Milnor Roberts, que foi contratado pelo governo imperial para perscrutar as potencialidades do Rio São Francisco de forma a promover uma maior integração nacional. Com seus diários 
da expedição, Theodoro Sampaio deu ao companheiro diversas informações relevantes sobre a geografia, o clima e a população da região.

Munido da documentação cedida pelo amigo e informado pelas palestras que mantinham, Euclides da Cunha passou a escrever artigos para o jornal O Estado de São Paulo, fazendo uma análise do conflito. Posteriormente, o periódico o contratou para, em loco, fazer as matérias sobre o conflito, o que acabou por gerar a monumental obra, Os Sertões, que contou em muito com a colaboração de Theodoro Sampaio na sua feitura.

Euclides começou a escrever. A princípio trazia-me aos domingos os primeiros capítulos, os referentes à natureza física dos sertões, geologia, aspecto, relevo, e mos lia naquela sua caligrafia minúscula que era como a minha também. A leitura fazia-se pausada a meu pedido, porque tinha eu a sensação de com ela estar a trilhar vereda nova, cheia de novidades. Não havia, porém, no novel escritor o abuso da adjetivação, tão comum aos novos. A frase saía-lhe perfeita, moldando-lhe com exatidão e nitidez as ideias. Uma propensão contudo se lhe notava e era a do emprego de termos desusados a que eu, a gracejar, chamava calhaus no meio de uma corrente harmoniosa - que de resto era a sua boa linguagem (SAMPAIO, 2000, p. 89).

Assim, percebe-se que desde a concepção da obra até a sua feitura, o amigo Theodoro Sampaio teve participação bastante ativa. Inclusive moderando o linguajar, por vezes antiquado, de Euclides da Cunha, embora este fosse mais jovem.

Contudo, a diferença entre os dois intelectuais não se atinha somente ao uso de termos rebuscados na escrita. Em verdade se encontravam em lados diversos na disputa política que tornava o conflito de Canudos tão relevante para o poder estabelecido. Enquanto Euclides, talvez devido ao seu passado nas forças armadas majoritariamente republicanas, era um republicano convicto, Theodoro Sampaio tinha uma muito boa relação com o antigo regime, embora parecesse ter uma relação respeitosa com o amigo, ao declarar. "O seu positivismo ou materialismo, já um tanto esmaecido, não colidia com o meu espiritualismo, por ele polidamente respeitado (SAMPAIO, 2000, p.86).

Embora classificado pelo amigo como positivista e, certamente tivesse tido bastante contato com as ideias positivistas de Comte, o próprio Euclides não se considerava como tal. Em carta para o político mineiro João Luís Alves (1870-1925), em 23 de abril de 1896, quando pretendia prestar concurso para professor da faculdade de Engenharia, escreveu, a queixar-se que alguém o havia prevenido que em São Paulo, concursos eram proforma, já haviam aqueles escolhidos para as vagas designadas. Inclusive, assegurava o informante, que já teria havido cancelamento de concurso por não haver passado o candidato previamente escolhido. Um outro presente à conversa, reproduzida na carta, ainda advertia a Euclides da Cunha que o fato deste participar da "seita posivista" era um agravante para a sua não aprovação, ainda que fosse bem qualificado nos exames, ao que Euclides da Cunha, concluía para o amigo mineiro, "eu positivista?” (GALVÃO, 1997, p. 93).

\section{A disputa Simbólica no império}

Segundo Lilia Shcwarcz (2002), o império, no seu segundo reinado, começou a deteriorarse durante a Guerra do Paraguai. No primeiro ano do conflito, que iniciou em dezembro de 1864, a imagem do monarca teve ganhos, o "rei guerreiro" tornou-se mais popular no imaginário de seus súditos. Mas, com o alongado da guerra, as despesas para sustentá-la, o número crescente de 
soldados enviados para o campo de batalha e as convocações compulsórias que levou muitos senhores de escravos a abrirem mão de seus cativos para que os substituírem no conflito, a imagem do monarca passou a sofrer danos. $\mathrm{O}$ fato foi agravado quando nos momentos finais do embate o Imperador tomou como questão pessoal a tarefa de eliminar Solano Lopez (SCHWARCZ, 2002, p. 295 - 296; 309-310).

A atitude radical e inesperada do monarca brasileiro, conhecido internacionalmente como um homem erudito, mecenas das ciências e das artes foi ao menos parcialmente substituída pela imagem de senhor da guerra, sanguinário e inflexível. O próprio Caxias dava a Guerra por encerrada após a tomada de Assunção em 1869, porém a teima do imperador em perseguir Lopes perdurou. A despeito dos apelos da princesa Isabel, o monarca enviou para o campo de batalha o seu genro, o conde D'eau, no lugar do demissionário Caxias, dando continuidade à perseguição do inimigo, culminando com a derrota do exército paraguaio desnutrido e a morte de seu chefe, Solano Lopez em Cerro Corá ${ }^{2}$.

O Império, entretanto, desde o final definitivo da guerra, perdurou por quase duas décadas até a proclamação da república, isso, após a última base de apoio político ao Império sentir-se traída pela abolição da escravidão em 1888 sem que houvesse um programa de indenização aos proprietários de escravos. Mas, o que chamamos a atenção neste artigo é para o fato de a simbologia do império sofrer um esvaziamento ao longo dos anos.

Se para todo sistema de governo os símbolos são fundamentais como propaganda e didática de convencimento para a adesão e naturalização do statu quo, os governos monárquicos têm verdadeira apreciação por toda essa simbologia. No entanto, o monarca brasileiro parecia cansado de seu longo reinado e isso transparecia nos símbolos da monarquia, tão importantes para a manutenção do sistema. Nos doze anos de correspondência entre D. Pedro II e o conde Gobineau ${ }^{3}$, que o recepcionou por duas vezes na Europa e o colocou em contato com vários intelectuais do Velho Mundo, era comum queixas como a subsequente.

Ah! Se minhas ocupações me permitissem outra existência que não esta que levo, ainda que sempre ocupado, como me sentiria feliz e então minhas leituras estariam de acordo com a vossa!

Hoje meu espírito está quase unicamente absorvido com o que resultará das eleições que já se iniciaram. Não preciso dizer-vos o quanto este assunto é antipático às Belas Artes e às Belas Artes assim como às aspirações da ciência. (Carta em 5 de agosto de 1878) (RAEDERS, 1938, p. 260)

Ocasionalmente, o imperador em suas cartas pessoais lamentava que seu destino como monarca já estava traçado e o quanto isso lhe era pesado, preferia dedicar-se às artes, às letras e às ciências em geral do que cumprir todos os protocolos de sua agenda de Estado. O fato é que a partir da década de setenta, com o fim do conflito armado, o imperador brasileiro, procurava portar-se como um cidadão ilustrado. A indumentária real, restringia-se às falas do Trono e fora isso,

\footnotetext{
2 Ver: SCHWARCZ, Lilia Moritz. As Barbas do Imperador: D.Pedro II, um monarca nos trópicos. São Paulo: Cia das Letras, 1998 e também DORATIOTO, Francisco. Maldida Guerra : Nova história da Guerra do Paraguai. São Paulo :Cia das Letras, 2002.

3 O conde Joseph Arthur de Gobineau (1816-1882) foi ministro plenipotenciário da França no Brasil no ano de 1869. Em verdade o conde foi designado para a função a contragosto, visto ser ele o autor do essai sur l'inégalité des races humaines (1853) que postulava ser a mistura de raças a causa da degenerescência do gênero humano. Contudo desenvolveu relação estreita com o Imperador, tendo recepcionado o monarca nas duas viagens que este empreendeu ao Velho Mundo.
} 
sua imagem de casaca e cartola era frequente tanto em suas aparições em público como nas múltiplas imagens de daquerreótipo que encantavam o soberano. D. Pedro abandonou também uma série de rituais como o beija-mão (SCHWARCZ, 2002, p.410).

Lilia Schwarcz (2002) chama a atenção para as impressões do prussiano, Carl von Koseritz (1830-1890), que vivia no Brasil e atuava como professor e jornalista. Este, ao descrever a corte carioca destacava a falta de luxo e de etiqueta, a pobreza da indumentária imperial, a decadência do palácio de São Cristovão e do Paço Imperial, o mal estado das carruagens, cuja douração se desgastara, tal qual a indumentária dos que acompanhavam o imperador (SCHWARCZ, 2002, p.410-412).

Conforme Bronislaw Backzko (1999), o poder político não está dissociado do imaginário coletivo. Assim, faz-se necessário para que o poder se estabeleça e se perpetue, ao menos por algum tempo, um investimento no imaginário simbólico que o legitime (BACZKO, 1991, p.12).

Ao desprezar os símbolos da própria realeza e investir na simbologia pessoal de literato, amante das artes e das ciências, sem que tais símbolos fossem vinculados à "sacralidade" de sua posição como monarca, o imperador brasileiro deixou um vazio no campo das representações que, certamente seria preenchido em algum momento. Talvez por esse motivo a queda do monarca foi quase imperceptível aos olhos da população em 1889, que "bestializada" assistiu os eventos, conforme veremos adiante.

Conscientemente ou não, o fato é que a república, então fundada, procurou preencher esse espaço do vazio simbólico de forma a propagar os ideais republicanos e positivistas como forma de criar raízes em solo nacional.

\section{A herança simbólica da República}

Em verdade a proclamação da República no Brasil não foi marcada por uma "queda da Bastilha à brasileira", embora houvessem alguns de ânimo mais acirrado que pedissem o fuzilamento do monarca D. Pedro II ou ainda do conde d'Eu, que, ao gosto desses, faria as vezes do infeliz Luiz XVI na nossa história, foram gritos isolados de uns poucos mais exaltados e que não tiveram eco nem mesmo entre as tropas que foram às ruas do Rio de Janeiro no 15 de novembro de 1889 (CARVALHO, 2003).

Segundo José Murilo de Carvalho, há diferentes versões para a irrupção do movimento, o que levou por muito tempo os partidários de Deodoro, Benjamin Constant, Quintino Bocaiuva e Floriano Peixoto a se digladiarem. Há relatos da chamada "guerra dos vivas", em que versões desencontradas afirmavam que Deodoro teria dado um viva ao imperador quando o movimento adentrou ao Quartel-General. Para cobrir a maçada do companheiro republicano, Benjamim Constant teria dado vivas à República e Deodoro teria censurado o segundo vivas, dizendo que ainda era cedo para derrubada da monarquia ou que fosse deixado à cargo do povo tal tarefa (CARVALHO, 2003, p. 36).

O historiador Capistrano de Abreu, em carta ao Barão do Rio Branco (1845-1912), relatava os fatos que vivenciou nos seguintes termos,

Recebi sua carta no dia 15 de novembro! Vinha do Campo de Santana impressionado, como pode imaginar, depois de ter visto uma revolução! Só há uma palavra que reproduz o que eu ví: empilhamento. Levantou-se uma brigada, chegaram os batalhões um a um, sem coesão, sem atração, 
sem resolução e foram-se encostando um a um, como peixe na salga. Quando não havia mais batalhão ausente ou duvidoso, proclamou-se a República, sem que ninguém reagisse, sem que ninguém protestasse $(\mathrm{RO}-$ DRIGUES, 1977, p. 127)

$\mathrm{Na}$ verdade, a República se deu de forma quase imperceptível pela maioria da população, mesmo no Rio de Janeiro, onde eclodiu o movimento, os mais de 500 mil habitantes pouco se deram conta. A ponto de Aristides Lobo, jurista e jornalista partidário da República, ter afirmado em artigo no Diário Popular, e 18 de novembro de 1889, "o povo assistiu àquilo bestializado, atônito, surpreso, sem conhecer o que significava", ou ainda o francês Louis Couty, que habitava no Brasil na época do movimento e que em sua análise afirmava "o Brasil não tem povo" (CARVALHO, 1987, p.50; MARTINS, 2008, p. 119).

Consoante José Murilo de Carvalho (2003) o movimento republicano no Brasil articulavase entre três grupos primordiais: o jacobinismo, que tinha por modelo a França e que utopicamente se pautavam pela democracia direta, com a participação de todos os cidadãos; o liberalismo à americana, cuja utopia era outra, a de uma sociedade composta por indivíduos autônomos e em busca de seus próprios interesses, os quais eram compatibilizados pela "mão invisível" concorrendo assim para o bem comum; também havia os positivistas, cujo ingredientes utópicos eram ainda mais salientes visto postularem uma sociedade que passasse por diferentes fases evolutivas, até alcançar o estado positivo ${ }^{4}$ (CARVALHO, 2003, p. 9-10).

A República já nascia dividida na minúscula elite que a proclamou sem qualquer apoio ou comoção popular. Dessa forma, fazia-se importante ocupar o vazio simbólico da monarquia com símbolos do novo poder que se instalou na nação, evitando assim que divisões políticas viessem a fazer malograr o movimento que insurgiu sem o povo ou mesmo que surgissem rupturas a fraturar a unidade nacional.

A manipulação do imaginário social é particularmente importante em momentos de mudança política e social, em momentos de redefinição de identidade coletivas. Não foi por acaso que a Revolução Francesa, em suas várias fases, tornou-se um exemplo clássico de tentativa de manipular os sentimentos coletivos no esforço de criar um novo sistema político, uma nova sociedade um homem novo. (CARVALHO, 2003, p. 11).

Nascida de parto tão inesperado, até mesmo para os seus agentes e sem que houvesse na massa populacional uma adesão mais apaixonada, a república precisava para a sua manutenção elencar elementos simbólicos que atraísse para si a legitimidade apaixonada que poderia fazê-la prosperar.

Todo poder busca monopolizar ciertos emblemas y controlar, cuando no dirigir, la costumbre de otros. De este modo, el ejecicio del poder, em especial del poder político, pasa por el imaginário colectivo. Ejercer un poder simbólico no significa agregar lo ilusório a um poderio "real", sino multiplicar u reforzar uma dominación efectiva por la apropriación de símbolos, por la conjugación de sentido y de poderio (BACZKO, 1999, p.16).

\footnotetext{
${ }^{4}$ Auguste Comte (1798 - 1857) propôs em seu, Curso de Filosofia Positiva, que cada ramo do conhecimento humano passa sucessivamente por três estados históricos diferentes: o estado teológico ou fictício; o estado metafísico ou abstrato; e o estado científico ou positivo. Em outras palavras, o espírito humano emprega, por sua natureza, sucessivamente, três métodos de filosofar, que parte do teológico, passa pelo metafísico e chega finalmente ao positivo.
} 
A vertente positivista da República brasileira, que estava associada ao nome de Benjamin Contant (1836-1891), era bastante afeita aos símbolos, os positivistas deixaram suas marcas em vários monumentos em bronze nas praças da capital Federal. Proposta desde 1892, o obelisco encimado por uma mulher - Clotilde de $\operatorname{Vaux}^{5}$ (1815-1846) com uma criança no colo, cena que representava a humanidade, tem abaixo a figura da esposa de Benjamin Constant segurando a bandeira da República e ainda a imagem heroica de Benjamin Constante com a espada em punho, voltado para o quartel general. Além desses símbolos, o monumento traz cenas da vida do homenageado, as figuras de Tiradentes, José Bonifácio e a reconstituição da Proclamação da República com Deodoro e Benjamim lado a lado (CARVALHO, 2003, p. 46-47).

Há ainda monumentos em diferentes praças que homenageiam Floriano Peixoto, encimado pela figura de mulher, representando a Pátria e um grupo em que se encontra o Marechal Floriano Peixoto, com a espada em punho e as figuras de Tiradentes, José Bonifácio e Benjamim Constante, que surgem da bandeira republicana. Além disso, o monumento tem uma profusão de símbolos de indígenas, Jesuítas e africanos.

A República carecia de heróis, para que o culto cívico fosse viável, a figura de Deodoro parecia a mais natural, porém sua posição como republicano era um tanto dúbia e, além disso sua figura física lembrava o velho monarca. Já Benjamim Constant era um republicano irretocável, porém, seu apelo era mais forte entre os jovens oficiais e no meio civil era praticamente conhecido apenas pelos positivistas. Floriano Peixoto, apagado no início, ganhou maior representatividade depois da Revolta da Armada no Rio de Janeiro e da Revolta Federalista no Sul do País. Porém, esse tinha uma visão favorável de Jacobinos, mas era visto como déspota pelos liberais (CARVALHO, 2003, p. 56-57).

Diante do impasse, o resgate da figura de Tiradentes foi bastante exitosa. Embora seu papel dentre o movimento dos inconfidentes, suas convicções e até mesmo sua aparência física sejam alvos de disputas historiográficas. Mas, um personagem distante historicamente, certamente é mais moldável às necessidades simbólicas do momento. Assim, o inconfidente de 1792, converteu-se em mártir heroico republicano, inclusive com sua imagem bastante associada à do Cristo.

A figura do inconfidente tinha o apelo popular necessário. Consoante José Murilo de Carvalho (2003), talvez o fato da conjuração mineira não ter chegado a concretizar-se, tendo a violência revolucionária permanecido latente, tornava mais santificada a figura do alferes com sua mortalha branca, colocando em maior destaque a violência do carrasco (CARVALHO, 2003, p. 68).

Muitos dos monumentos em bronze espalhados pela cidade do Rio de Janeiro têm a representação da bandeira nacional. Esta é uma simbologia bastante significativa nos Estados-Nação e não poderia deixar de ser alvo de atenção da República brasileira, ávida por divulgar seus símbolos. No 15 de novembro, dia da proclamação, o movimento republicano não tinha em mãos aquele símbolo mais básico de um movimento organizado, a bandeira. Em verdade não havia também um hino republicano brasileiro e para suprir essa falta no caráter representativo os insurgentes cantavam a Marselhesa, que fazia alusão à República francesa que inspirava a ala positivista do movimento. (CARVALHO, 2003, p.114).

Uma possibilidade de estandarte, seria a própria bandeira dos inconfidentes, outra opção era algum dos modelos inspirados na bandeira estadunidense, uma destas foi levada pelos

\footnotetext{
5 Clotilde de Vaux (1815 -1846) foi uma escritora francesa que tornou-se a musa inspiradora de Auguste Comte. A relação dos dois não se concretizou já que Clotilde de Vaux era separada de seu primeiro casamento. Inspirado no amor platônico, ambos fundaram a Religião da Humanidade que pretendia-se um degrau na evolução humana rumo ao estado positivo.
} 
republicanos civis à rua no fatídico dia 15 e chegou a ser hasteada por José do Patrocínio (18531905) na Câmara Municipal, onde permaneceu até o dia 19. Porém tudo era improviso. Embora houvesse entusiasmo pela república estadunidense, a grande referência dos republicanos brasileiros era a França e a maioria dos partidários voltavam seus olhos com mais simpatia para o positivismo francês do que para a democracia no estilo dos americanos do Norte.

Outra candidata foi a bandeira hasteada no navio Alagoas que transportou a família imperial para o exílio. $\mathrm{Na}$ descrição de Afonso Celso, que partiu em exílio num navio que acompanhava de perto o do imperador,

Um de nós empunhava o binóculo, soltou uma exclamação. O verde e amarelo do tope nacional refira-lhe a retina, flutuando em navio ainda afastado - o mais vizinho da praia. Mas a bandeira nos era entranha; um plágio da dos Estados Unidos da América do Norte, estrelas agrupadas num ângulo, listras horizontais paralelas. Somente as cores variavam.

O vapor, conhecemo-lo imediatamente. Era o Alagoas, fretado pelo governador revolucionário para levar ao desterro a família imperial e alguns íntimos (AFFONSO CELSO, 2013, p.72).

As formas, as cores e as alusões fossem à França ou aos Estados Unidos era motivo de disputa entre os diferentes grupos que proclamaram a República. Uma delas, (justamente a que fora hasteada na Câmara, quando o movimento eclodiu), foi criada em 1888 para recepcionar Lopes Trovão que, na época, regressava de uma viagem pela Europa. Segundo consta o quadrilátero dessa bandeira, baseada na congênere estadunidense, era de cor preta para homenagear a raça negra brasileira. Simbologia que não permaneceu em nenhum dos estandartes posteriormente. Inclusive a que foi hasteada no navio que conduziu a família imperial para o exílio, cópia da primeira, já trazia o quadrilátero azul, segundo alguns relatos. José Murilo de Carvalho, chama a atenção para o fato e questiona se a mudança da cor teve motivações estéticos ou racistas? (CARVALHO,2003, p. 112).

Até que se chegasse à versão final da bandeira, muita discussão houve entre os envolvidos. Um dos pontos fulcrais do debate foi o lema positivista "ordem e progresso" como divisa. Enquanto Teixeira Mendes (1855-1927) advogava que o lema cumpria o papel de evocar o futuro desejável para a Nação, inserindo-a numa nova dinâmica de confraternização universal, os opositores alegavam que a nova bandeira cumpria um papel ridículo ao vincular-se à seita positivista. Assim tratava em 10 de janeiro de 1891, o Díario do Commercio num artigo intitulado Reformemos a Bandeira,

O Diário do Commercio sempre clamou contra a adoção da atual [bandeira], porque tem os distintivos e o lema de uma seita, imposição odiosa aos crentes das outras religiões.

Pedimos que fosse adotada a ideia do Sr. Marechal Deodoro. Isto foi resolvido, os jornais o publicaram e 24 horas depois tanto clamaram os quatro ou cinco membros do capítulo diretor da referida comunhão, cuja divisa tem o lema da bandeira, que prevaleceu esse empenho contra a vontade do ditador e do povo (Diário do Commercio, 10/01/1891).

$\mathrm{O}$ artigo segue criticando os positivistas que passaram longo tempo a buscar símbolos que fizessem menção à sua "seita", desconsiderando o debate coletivo e impondo a sua vontade. Figuras procuravam ridicularizar a bandeira e seus criadores e em especial o lema positivista que nela se inseria. 
De Hercules se conta que para o dar à luz gemeu Alcmena sete dias e outras tantas noites; no fim das contas saiu um meninão que que ainda no berço afogava serpentes; mas do sr. Teixeira Mendes, após seis meses com dores de parto, espirrou um monstrengo tão enfezado quanto o próprio progenitor (Diário do Commercio, 10/01/1891).

Em seguida chamando a atenção para a posição das estrelas, que na bandeira, não correspondiam à exata posição dos astros, duvidava da formação de Teixeira Mendes, a quem atribuíram o adjetivo de "pajé positivista". Havia, contudo no artigo reprodução da defesa de Mendes, que da mesma forma desqualificava os jornalistas, colocando em dúvida a formação desses,

E quem escreve isto é um pedagogo que possui um diploma em virtude do qual deve saber astronomia! Pois um "baxarel” ( baxarel com X será S.S.) em matemática e professor de "jeografia" ignora que todos os elementos que definem o movimento planetário não têm a fixidez que as pessoas estranhas à ciência imaginam?

Assim, percebemos que a disputa pelos símbolos da República recém fundada era bastante acirrada. Eleger um inimigo comum, uma ameaça à integridade nacional é uma tática bastante conhecida para promover a união de um povo. Podemos pensar tal fato como parte da simbologia republicana, já que cumpre todos os requisitos advindos destes signos, como propagandear o sistema político, unir a população em torno de um ideal, informar, acender paixões etc.

Não podemos afirmar que isso, no caso da República brasileira tenha se dado de forma maniqueísta ou espontânea, mas o fato é que a ameaça da restauração era uma forma eficaz de unir as diferentes linhagens republicanas em defesa da República, e acirrar os ânimos se em torno de uma pretensa reação monárquica.

O velho imperador em seu exílio declarara, "jamais conspirarei para voltar, nem desejo que conspirem em meu nome; mas se me chamarem espontaneamente, não hesitarei um segundo: regressarei sem detença e com satisfação" (AFONSO CELSO, 2013, p. 76). Tal disposição de retomar o trono por parte do monarca exilado, excitava a imprensa monarquista. Porém, aqueles que sonhavam com a volta do monarca e a restauração do império viram malograr seu desejo em 5 de dezembro de 1891 quando D. Pedro morreu no exílio.

\section{O inimigo monárquico}

Por mais que a monarquia tenha ruído tão facilmente diante do avanço republicano, evidentemente o antigo regime deixou marcas importantes na sociedade brasileira, especialmente o segundo reinado sob um único soberano.

Algumas instituições, como o Instituto Histórico Geográfico Brasileiro - IHGB eram profundamente vinculado à monarquia. Fundado em 1838 e transferido para o Paço da Cidade em 1841, sob a proteção direta do imperador D. Pedro II, era natural que o Instituto estivesse muito ligado ao império.

Apesar dos esforços de Araripe Júnior (1848 -1911) e de seu pai Tristão de Alencar Araripe (1821-1908), que fazia parte do primeiro ministério e Deodoro em preservar o IHGB, este era visto pela cúpula do poder como uma herança do ancien régíme a ser extinto e o corte radical das verbas destinadas àquela Casa atestava a má vontade dos republicanos para com o Instituto Histórico (GUIMARÃES, 2007,p.22).

Não era segredo o apreço que os membros do Instituto nutriam pelas figuras do monarca, 
havia, inclusive uma cadeira que, outrora ocupada pelo imperador, permanecia vazia nas seções do Instituto, como que esperando a volta de seu legítimo ocupante. Além disso, as manifestações de pesar quando do anúncio da morte do imperador, o Instituto guardou luto fechado, mandou celebrar missa solene de sétimo dia e, em homenagem ao falecido, passou a nomear a sala onde aconteciam as reuniões acadêmicas de Sala de d. Pedro II (GUIMARÃES, 2007, p.22).

Não somente, algumas instituições como o IHGB, mas alguns jornais monarquistas insistiam em sua propaganda antirregime, o que acirrava a disputa dos republicanos com a ameaça da restauração.

Em 1896, a figura de Antônio Conselheiro era conhecida, inclusive internacionalmente, como relatava a Gazeta da Tarde de 26 de abril daquele ano, ao reproduzir artigo de um periódico português,

Há na povoação de Loureiro, d'este concelho, um homem de 90 anos chamado Heitor, que de tal forma se dedicou à vida religiosa que é tido e havido como santo. É descendente de uma família abastada, e dispôs de meios bastante[...]. O que é certo é que se dedicou do fundo d'álma à vida religiosa. Há quarenta anos mandou construir uma capela n'uma propriedade sua, e aí está de joelhos todos os dias desde as 6 horas da tarde, tendo os joelhos em sangue, bem como as mãos, que põe por debaixo deles.

[...]O santo para todos os males tem remédio [...]. Calcula-se em número superior a 200 as pessoas que o visitam diariamente (Gazeta da Tarde de 26 de abril de 1896).

Percebe-se pela descrição que o beato dificilmente representaria um foco de resistência eficiente para a restauração, mesmo porque o monarca já havia falecido no exterior, porém a batalha no campo simbólico travou-se de forma acirrada. Um dos pontos altos desse embate se deu por meio da imprensa, pois jornais republicanos acusavam monarquistas de financiarem os seguidores de Conselheiro, para desestabilizar o governo republicano.

Uma das figuras chaves nessa disputa eram o Visconde de Ouro Preto (1836-1812) e seu filho, Afonso Celso de Assis Figueiredo Júnior (1860-1838). Este último foi deputado por Minas Gerais no período monarquista e escandalizara a plenária da Câmara afirmando-se republicano. Contudo, ao voltar da Europa para onde partiu em navio que acompanhou a Alagoas, citada nau que levou a família imperial para o exílio, lançou um livro que rememorava sua convivência com D. Pedro no Velho Mundo, Vultos de fatos, que vendeu seis mil exemplares, um best-seller para os padrões da época. Levando-o a ser conhecido pelo inevitável mote de "republicano no Império e monarquista na República" (SOUSA, 2012, p. 157).

Quando em 1897, a expedição liderada pelo Coronel Moreira Cezar sofreu uma fragorosa derrota frente aos revoltosos de Antônio Conselheiro, Jornais Republicanos como a Gazeta de Notícias atacaram, com afirmações infundadas de que "monarquistas revolucionários querem destruir com a República e a unidade do Brasil", fato que nossa geração denominaria como fake News e que tão profundamente marcou os últimos anos da política nacional.

O Coronel Gentil de Castro, proprietário dos jornais monarquistas Gazeta da Tarde, Gazeta da Liberdade e do Apóstolo, juntamente com o Visconde de Ouro Preto e seu filho, Afonso Celso, estavam no centro das acusações.

Os ânimos acirrados levaram um grupo de republicanos ao empastelamento dos jornais, bem como um ataque à casa de Gentil de Castro. A situação fez os três acusados de insuflarem os revoltosos de Canudos descerem a Serra de Petrópolis, onde se encontravam, para averiguar os prejuízos. Feito isso, encontravam-se na Estação Ferroviária de São Francisco de Xavier para 
retornarem a Petrópolis, quando sofreram um atentado. Gentil de Castro foi alvejado e veio a falecer, enquanto o Visconde de Ouro Preto e Afonso Celso conseguiram escapar (SOUSA, 2012, p. 160).

Percebe-se pela gravidade dos fatos que a manipulação de símbolos que invocam lutas sectárias é extremamente eficientes para acender paixões e promover ações radicais.

\section{Euclides da Cunha e o imaginário dos Sertões}

Na citada homenagem que o engenheiro Theodoro Sampaio fez a Euclides da Cunha nos dez anos de sua morte, o autor citava que o homenageado chegou a acreditar numa articulação monarquista para desestabilizar a República e, mesmo quando foi despedir-se, quando partia como correspondente de $O$ Estado de S. Paulo, para seguir de perto a coluna expedicionária do comando do General Arthur Oscar em 1897.

Naquele mesmo ano, Euclides da Cunha escreveu seu primeiro artigo para O Estado de S.Paulo, em que classificava os seguidores de Antônio Conselheiro de "horda de fanatizados sequazes" e o líder do movimento de "o mais sério inimigo das forças republicanas" ou ainda que "o fanatismo religioso que domina as suas almas ingênuas e simples é habilmente aproveitado pelos propagandistas do império (O Estado de S. Paulo, 4 de março de 1897).

Assim, cooptados pelos monarquistas, o sertanejo lutaria fanaticamente até o fim contra a República, que aos olhos de Euclides da Cunha, ainda que decepcionado com o modelo republicano que se instalou no Brasil, não duvidava que esta representava a modernidade, enquanto o sertanejo e o Império eram o atraso que precisava ser superado. O intelectual terminava o artigo com uma frase ufanista, “A República sairá triunfante desta última prova”. (O Estado de S. Paulo, 4 de março de 1897).

O que podemos inferir do texto original de Euclides da Cunha acerca dos sertanejos da região do Vaza-Barris, local no Norte baiano em que se concentravam os seguidores de Antônio Conselheiro era bastante marcada pelo arcabouço simbólico que mobilizava os republicanos da capital federal. Somando-se a isso uma visão da "raça sertaneja", ao identificá-los como "um tipo etnologicamente indefinido ainda" como um tipo etnológico inacabado. (O Estado de S. Paulo, 4 de março de 1897).

Para Fernando Catroga o sentido de "pátria" está ligado a população e, em certa medida, o território tende a estar em primeiro plano frente à face institucional e mesmo funcional, já que os signos que movimenta são de caráter lírico, afetivo e maternal que antropomorfiza o território, transformando-o em paisagem quanto a população, que tende a se conglomerar em uma identidade fraterna de com/patriotas. Já o sentido de estado, alude, predominantemente a uma dimensão institucionalizada que exerce poder sobre a população e, por conseguinte sobre um dado território. Divide-se assim o grupo entre governantes e governados que partilham um dado território, com limites bem definidos, sendo o exercício do poder fruto de um pacto em que governantes detêm o monopólio da violência para defender o Estado de inimigos internos ou externos. Assim, o Estado guarda em sua linguagem um arcabouço técnico-jurídico e "frio" em comparação com o vocabulário elencado por pátria conforme assinalamos.

Nesse aspecto o termo Nação estaria mais próximo à pátria, sendo que a origem semântica do último está vinculada à concepção, enquanto no caso de nação o vínculo é ao nascimento. Ainda que os termos se confundam em seu uso cotidiano ao longo dos séculos, podemos inferir que os nacionalismos nos séculos XVI e XVII tinham um sentido de pacto secular (contrato social) e que 
nos séculos XIX e XX passam a vincular-se a uma caracterização étnico-linguística, o que veio a ter implicações nas teorias sobre estado e sobre a própria ideia de pátria e de patriotismo. Sem entrarmos na discussão de se os estados modernos seguiram o sentido de Estado para Nação ou vice-versa, podemos pensar a nação como a instância de conexão entre o "calor" da pátria e a "frieza" do estado (CARTROGA, 2008, p.20).

Com base nas reflexões anteriores podemos pensar que Euclides da Cunha partia para Canudos com uma missão de Estado. Como visto, em seu primeiro texto sobre o conflito na região, publicado no Estado de São Paulo, o intelectual via nos sertanejos revoltosos, a imagem do atraso frente à modernidade que se apresentava como a República. Chegava mesmo a questionar se os sertanejos, seguidores do beato Conselheiro não estariam sendo financiados por imperialistas que buscavam a restauração.

Contudo, as impressões de Euclides da Cunha vão, ao deparar-se com a realidade daquela região e a realidade da população sertaneja a serem matizadas, tornando-se mais ricas, sensíveis e reflexivas, buscando naquela situação de crise um sentido de nação que pudesse fazer sentido no mosaico da pátria.

Como amalgamar os diferentes elementos étnicos presentes no território forjando um sentido de nação não era tarefa que a frieza do Estado seria suficientemente penetrante para solver.

Adstrita às influências que mutuam, em graus variáveis, três elementos étnicos, a gênese das raças mestiças do Brasil é um problema que por muito tempo ainda desafiará o esforço dos melhores espíritos (CUNHA, 2003, p.97)

Euclides da Cunha passou a pensar os três elementos fundamentais, procurando descrever os elementos indígenas desde a sua formação, pensando a América como um centro de criação desligado do "grande viveiro da "Ásia Central", teria dado origem de forma autônoma ao homo americanos, este por meio de cruzamentos posteriores com alguma raça invasora do norte, teria, supostamente originado os tupis.

Seguindo o seu raciocínio introduziu a análise sobre os negros, banto ou cafre com as suas várias modalidades. Assim como dos indígenas, afirma que pouco se sabe sobre esse segundo elemento, introduzido via tráfico negreiro. Dos primeiros ainda há estudos arqueológicos e de etnólogos, já o segundo, destaca apenas Nina Rodrigues, médico maranhense que desvendou muito da religiosidade dos africanos transplantados para o Brasil.

Por último chamou à cena o "fator aristocrático de nossa gens", o português, que segundo o autor, "nos liga à vibrátil estrutura intelectual do celta" e destacou que é sobre esse elemento que mais temos informações. (CUNHA, 2003,p.98)

Para complicar a equação, Euclides da Cunha atestava que a mistura das raças não resultaram num só elemento sobre o qual se poderia erigir uma nação, mas num mosaico ainda mais complexo e com diferentes matizes, onde se destacavam como produtos mais característicos o mulato, o mameluco ou curiboca, e o cafuz. Nesse caso as indagações iniciais do autor se convertem em questões muito mais complexas se a intenção era pensar a nação como uma homogeneidade racial.

Como um intelectual de seu tempo, é compreensível que Euclides da Cunha procurasse na chave das raças a identidade nacional que procurava como simbologia para a jovem república. Não somente isso, mas o fator climático era um ponto importante para autores oitocentistas que buscavam entender o que chamavam de "caráter nacional". 
O que se percebe em Os Sertões é que seu autor, ainda que eivado pelos símbolos da república, não deixou de observar com alguma sensibilidade o sertanejo, e com os instrumentos da ciência oitocentista que dispunha tenda decifrar aquele quadro, como quem decifra a esfinge. Porém, parece pessimista ao vaticinar, "não temos unidade de raça" e completa, "não teremos talvez nunca" (CUNHA, 2003, p. 102).

Embora não faça menção em sua obra de Hippolyte Taine (1828 -1893), fica patente que Euclides da Cunha busca socorro no historiador positivista para interpretar e dar sentido àquele quadro que tentava decifrar. Os pressupostos do autor do Velho Mundo encontram-se presentes nos escritos do intelectual brasileiro, os quais seriam "raça, meio e momento". Evidentemente um erudito como Euclides da Cunha não se vinculava a somente uma vertente, há também em sua obra a perspectiva antropogeográfica de Ratzel, em alguma medida o determinismo de Buckle e outros autores bastante lidos na segunda metade do século XIX no território brasileiro.

O método de Taine foi bastante utilizado em Histoire da la Littérature Anglaise, obra na qual o autor procura penetrar no caráter do povo inglês, desvendar-lhe a alma ou a psicologia a partir da arte produzida por aquele povo. Para aquele autor, a história seria um ato de ressurreição do passado, não tanto do passado factual, mas do passado interior de um povo (SOUSA, 2012,p. 46).

A chave para essa "ressurreição" seria o que chamava de "três fontes", as já citadas raça, meio e momento. Sendo que a primeira, tratava-se das disposições inatas e hereditárias dos seres humanos e que ordinariamente se juntam às diferenças marcadas pelo temperamento e estrutura dos corpos.

O meio, portanto, imprimia com bastante eficácia sua marca na população que nele construía a sua subsistência, porém essas marcas não eram dispostas como numa tábula rasa.

Já, o momento, seria o próprio acaso, ou a circunstância que ocasionaria que o meio imprimisse a sua marca na raça de formas diferenciadas já que, em momentos diversos, tais marcas tendiam a serem diversas. Não havendo, portanto, uma fórmula exata.

A raça ariana, por exemplo, no seu processo migratório teria dado origem a diferentes povos arianos como os germânicos, os helênicos e os latinos. As diferenças entre esses grupos se dava devido à proximidade de um mar navegável, convidativo ao comércio, o regime de chuvas, as florestas etc. tudo atuaria no temperamento do ser humano tornando-o melancólico, irascível, inclinado à embriaguez ou à glutonaria, ou ainda afeito à vida militar, à poesia, ao talento de desfrutar de invenções científicas ou à arte

O meio agiria, portanto, excitando determinados sentidos e adormecendo outros latentes, trazendo à tona características inerentes à raça. Essa concepção de meio, segundo Natalie Richard (2009) a noção de meio em Taine provavelmente era inspirado em reflexões de Claude Bernard e ainda às teorias climáticas de Montesquieu e Buffon (RICHARS, 2009, p. 128).

$\mathrm{Na}$ obra de Euclides da Cunha, são várias as passagens em que o meio físico e o sertanejo aparecem como complementares. Não raro as características de um e de outro se fundem numa só, absolutamente integradas. Um exemplo disso é que ao descrever a natureza local, o autor percebe mudanças abruptas, em que a terra seca e aparentemente sem vida se transmuta como que num passe de mágica, revelando um potencial latente de abundância e vigor.

Quem se aventura nos estios quentes à travessia dos sertões do Norte afeiçoa-se a quadros singulares. A terra, despindo-se de toda a umidade — numa intercadência de dias adustivos e noites quase frias - ao derivar para o ciclo das secas parece cair em vida latente, imobilizando apenas, sem o decompor, os seres que sobre elas vivem. Realiza, em alta escala, o fato fisiológico de uma existência virtual, imperceptível e surda — energias encadeadas, adormecidas 
apenas, prestes a rebentarem todas, de chofre, à volta das condições exteriores favoráveis, originando ressurreições improvisas e surpreendedoras. E como as árvores recrestadas e nuas que, à vinda das primeiras chuvas, se cobrem, exuberando seiva, de flores, sem esperar pelas folhas, transmudando em poucos dias aqueles desertos em prados — as aves que tombam mortas dos ares estagnados, a fauna resistente das caatingas que se aniquila, e o homem que sucumbe à insolação fulminante, parecem, jazendo largo tempo intactos, sem que os vermes lhes alterem os tecidos, esperar também pela volta das quadras benfazejas (CUNHA, 2003, p. 602).

Da mesma forma que a natureza sertaneja se transmuta, o sertanejo o faz. São célebres as passagens em que o sertanejo enfraquecido e acabrunhado magicamente se transforma de Quasímodo em Hércules. Com essa figura Euclides da Cunha mostra que o sertanejo é como sua terra, parece a um primeiro olhar um deserto desenganado, porém basta-lhe um estímulo e o Quasímodo, personagem desfigurado de Victor Hugo (1802 - 1885) na obra Notre Dame de Paris, se transfigura na personagem heroica de Hércules da mitologia grega ou ainda de "Titã acobreado"

É o homem permanentemente fatigado.

Reflete a preguiça invencível, a atonia muscular perene, em tudo: na palavra remorada, no gesto contrafeito, no andar desaprumado, na cadência langorosa das modinhas, na tendência constante à imobilidade e à quietude.

Entretanto, toda esta aparência de cansaço ilude.

Nada é mais surpreendedor do que vê-la desaparecer de improviso. Naquela organização combalida operam-se, em segundos, transmutações completas. Basta o aparecimento de qualquer incidente exigindo-lhe o desencadear das energias adormecidas. O homem transfigura-se. Empertiga-se, estadeando novos relevos, novas linhas na estatura e no gesto; e a cabeça firma-selhe, alta, sobre os ombros possantes aclarada pelo olhar desassombrado e forte; e corrigem-selhe, prestes, numa descarga nervosa instantânea, todos os efeitos do relaxamento habitual dos órgãos; e da figura vulgar do tabaréu canhestro reponta, inesperadamente, o aspecto dominador de um titã acobreado e potente, num desdobramento surpreendente de força e agilidade extraordinárias.

Assim, a imagem da Vendéia brasileira vai se desfazendo ao longo do relato, e embora Euclides da Cunha não se desfaça de seus preceitos cientificistas, que no século XIX eram eminentemente racialistas, como percebemos nos princípios básicos de Hyppolite Taine, acaba por alcançar certa empatia com o sertanejo. Em um dos trechos afirmou: "Era um derivativo à exacerbação mística; uma variante forçada ao delírio religioso. Mas, não traduzia o mais pálido intuito político" e, na continuidade do texto segue o elemento racial que não abandona "o jagunço é tão inapto para aprender a forma republicana como a monárquica-constitucional” (CUNHA, 2003, p. 268).

\section{Considerações Finais}

Os Sertões é uma obra marcada pelo seu tempo, pelo seu autor e por conseguinte, um conjunto de símbolos elencados que, em alguma medida, se encaminhava para a eleição de Antônio Conselheiro e seus seguidores como inimigos a serem enfrentados pela República. Esta nasceu dividida, no vácuo das simbologias do governo monárquico que ruiu sem estrondo.

Euclides da Cunha era um homem sensível ao o arcabouço simbólico de seu tempo, bem como um literato crente na ciência e no progresso. Ao deparar-se com a realidade sertaneja, a qual já havia interpretado segundo os signos da República, acaba por matizar seu olhar.

Ainda que os instrumentos da ciência com que se referenciava estivessem moldados aos 
parâmetros eurocêntricos, o autor de Os Sertões, em alguma medida, descreveu em sua obra o cotidiano da população sertaneja, percebeu o quanto era infundada a construção daquela como inimiga real da República e percebe como descabido e sanguinário foi o massacre àquela população pelo poder público. Podemos afirmar que Euclides da Cunha contribuiu para uma construção simbólica do sertanejo e até mesmo do brasileiro como "o forte" que resiste aos piores infortúnios e se reergue. Contudo, na construção Euclidiana, ao fim e ao cabo, aquela gente estaria fadada ao desaparecimento no processo evolutivo.

\section{Referências}

AFONSO CELSO, Afonso Celso de Assis Figueiredo Jr., conde de. O imperador no exílio. São Paulo: Linotipo Digial,2013.

BACZKO, Bronislaw. Los imaginários sociales: Memorias y esperanzas. Buenos Aires: Ediciones Nueva Vision, 1991.

CARVALHO, José Murilo. Bestializados: o Rio de Janeiro e a República que não foi. São Paulo: Companhia das Letras, 1987.

CARVALHO, José Murilo. A formação das almas: 0 imaginário da República no Brasil. São Paulo: Companhia das Letras, 2003.

CATROGA, Fernando. Pátria, nação, nacionalismo. In: TORGAL, Luís Reis et ali. Comunidades imaginadas: Nação e nacionalismos em África. Coimbra: Imprensa da Universidade de Coimbra, 2008. CUNHA, Euclides. O Estado de S. Paulo, 4 de março de 1897.

CUNHA, Euclides da. Os Sertões. São Paulo: Ediouro, 2003.

Diário do Commercio, Reformemos a nossa bandeira,10 de janeiro de 1891.

Gazeta da Tarde, 26 de abril de 1896.

GALVAO, Walnice Nogueira \& GALOTTI, Oswaldo. Correspondência de Euclides da Cunha. São Paulo: Editora da Universidade de São Paulo, 1997.

GUIMARÃES, Lucia M. P. Da escola palatina ao silogeu: Instituto Histórico e Geográfico Brasileiro (1889 - 1938). Rio de Janeiro: Ed. Museu da República. 2007.

MARTINS, Luís. O patriarca e o bacharel. São Paulo: Alameda, 2008.

RAEDERS, Georges. D. Pedro /l e o conde de Gobineau: correspondências inéditas. São Paulo: Cia Editorial Nacional, 1938.

RICHARD, Nathalie. Au creuset des sciences humaines. La Science de l'homme au temps de Renan et de Taine. Paris: Université Paris I - Panthéon - Sorbone, 2009.

RODRIGUES, José Honório (org.). Correspondência de Capistrano de Abreu (vol.1). Rio de Janeiro: Civilização Brasileira, 1977.

SAMPAIO, Theodoro. O rio São Francisco e a Chapada Diamantina. São Paulo: Cia das Letras, 2002.

SAMPAIO, Theodoro. Recordando Euclides da Cunha (no décimo aniversário de sua morte). In: CUNHA, Euclides da (1866-1909). Um paraíso perdido: reunião de ensaios amazônicos/ Euclides da Cunha; seleção e coordenação Hildon Rocha. Brasília: Senado Federal, 2000, p. 85-94.

SCHWARCZ. Lilia Moritz. As Barbas do Imperador: D. Pedro II, um monarca nos trópicos. São Paulo: Cia das Letras, 2002.

SOUSA, Ricardo. Capistrano de Abreu: História Pátria, Cientificismo e Cultura a Construção da História e do Historiador. Tese de doutorado, apresentada ao Curso de Pós-Graduação em História 
das Ciências e da Saúde da Casa de Oswaldo Cruz - FIOCRUZ, Rio de Janeiro, 2012.

Artigo recebido em: 20/06/2020

Artigo aceito em: 30/07/2020 